\title{
What is a Substantial Contribution to a Research Project in Offensive Cyberspace Operations that Merits Co-Authorship?
}

\author{
Gazmend Huskaj \\ Department of Military Studies, Swedish Defence University, Stockholm, Sweden \\ School of Informatics, University of Skövde, Sweden \\ gazmend.huskaj@fhs.se
}

\begin{abstract}
This article reviews the question what is a substantial contribution to a research project in offensive cyberspace operations that merits co-authorship? Frustrations and conflicts may develop during research projects when researchers with different backgrounds, cultures, research fields and expertise decide to conduct research and produce and publish those results. The focus of this paper is a research project in cyberspace operations while taking into account the power-dynamics inherent in the academic system and how these can affect the co-authorship of research products. First, the purpose with doing research is presented. Next, three models of the research process are reviewed, describing their differences and similarities. Then, linguistic analysis is applied on a set of terms in guidelines for co-authorship described in some different universities in Sweden. The results present a model for a research project in offensive cyberspace operations and based on the output of the linguistic analysis, the model is used to quantify and describe what a substantial contribution is in three scenarios that merits co-authorship.
\end{abstract}

Keywords: Co-authorship, Linguistic Analysis, Offensive Cyberspace Operations, Power-dynamics, Substantial Contribution

\section{Introduction}

Frustrations and conflicts may develop during research projects when researchers with different backgrounds, cultures, research fields and expertise decide to conduct research and produce and publish those results (NTNU, 2021). The same frustrations and conflicts may also arise between a PhD-student and his/her supervisor(s), especially during a PhD research project that tends to span over several years. It is known that a PhD research project has psychological, emotional and other aspects like "enthusiasm, isolation, boredom, frustration, anxiety and euphoria" (Morrison-Saunders et al., 2010, p. 3) that can affect the PhD-student and his/her supervisor(s) in various ways. Frustrations have been reported between students and supervisors in cases of lack of feedback, supervisors changing their mind often, and students having to wait "for what they considered unreasonable periods, for supervisors to provide feedback and guidance on thesis drafts" (Morrison-Saunders et al., 2010, p. 9). Additional frustrations and conflicts have arisen in cases where supervisors have not been invested in the PhD-project, the supervisee felt lack of support, the supervisee being more experienced than the supervisor, and the supervisor being too busy (Nelson \& Friedlander, 2001).

Another area where frustrations and conflicts may arise is during research projects where the PhD-student and his/her supervisor(s) co-author research products. While co-authoring affects how productive a researcher is, there are also addition positive aspects such as feeling safer (Tschannen-Moran \& Nestor Baker, 2004), having more fun and to the actual production of a research product (Nygaard, 2017). The negative aspects can arise when the PhD-student and the supervisor(s) disagree on what a substantial contribution to a research project is because of differing perspectives the supervisee and supervisor(s) may have on co-authorship. In one coauthoring case, a supervisor took credit for a PhD-student's work: "I think I've seen some kind of dark, underbelly of academia. ... But, when you've seen that a couple of times, you're also going to start to get more wary. ... I think it's a rotten, rotten thing, co-authorship" (Nygaard, 2017, p. 526).

A PhD-project spanning over several years, the psychological and emotional aspects coupled with supervisors that take time to provide feedback, not being invested in the PhD-project, not providing enough of support, being too busy, having different perspectives on co-authorship, and being inexperienced in comparison to the PhD-student, are all elements that lead only in one direction: frustration, conflict, and in some cases, the PhDstudent being the one to take the fall (Times Higher Education, 2017). Therefore, it is important to review the question what is a substantial contribution to a research project in cyberspace operations that merits coauthorship.

The remainder of the paper is as follows: First, the reason why and those that do research is covered. Next, the research project is described followed by the method and linguistic analysis (Goldkuhl, 2002), which is applied throughout the paper. Finally, substantial is quantified followed by conclusions and why this is important. 


\section{Gazmend Huskaj}

\section{Why do Research?}

There are many reasons to why people do research:

"add to the body of knowledge, to solve a problem, to find out what happens, to find the evidence to inform practice, to develop a greater understanding of people and their world, to predict, plan and control, to contribute to other people's well-being, to contribute to personal needs, to test or disprove a theory, to come up with a better way, to understand another person's point of view, [or] to create more interest in the researcher" (Oates, 2005, pp. 17-21).

The outcomes of research are different research products (Oates, 2005). A reader with a background in the security and intelligence services will note the word "products." Why? Because Intelligence is about knowing other States' secrets and using those secrets to achieve one own's national interests, but also to secure those national interests. Intelligence operations are also vital in supporting military operations (Joint Chiefs of Staff [JCS], 2013). The Intelligence process is about the actions as mentioned in Figure 1. These actions are done in a cycle, also known as the Intelligence Cycle. Once the analysis is done, a report is produced, and this report is known in Intelligence parlance as an "Intelligence Product." Therefore, when Oates (2005) states that the outcome of research are different research "products", this indicates that research may actually have a lot in common with Intelligence operations and the Intelligence process.

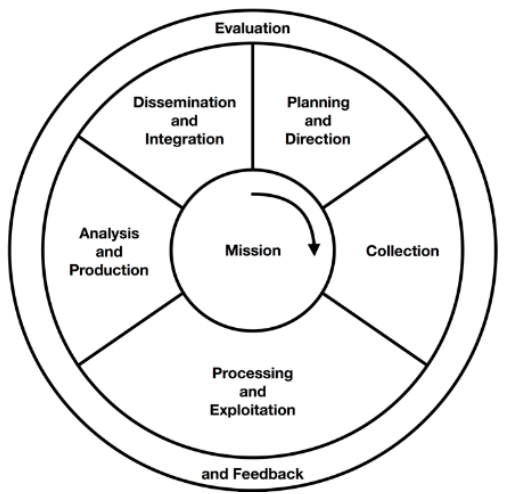

Figure 1: The Intelligence Cycle (JCS, 2013)

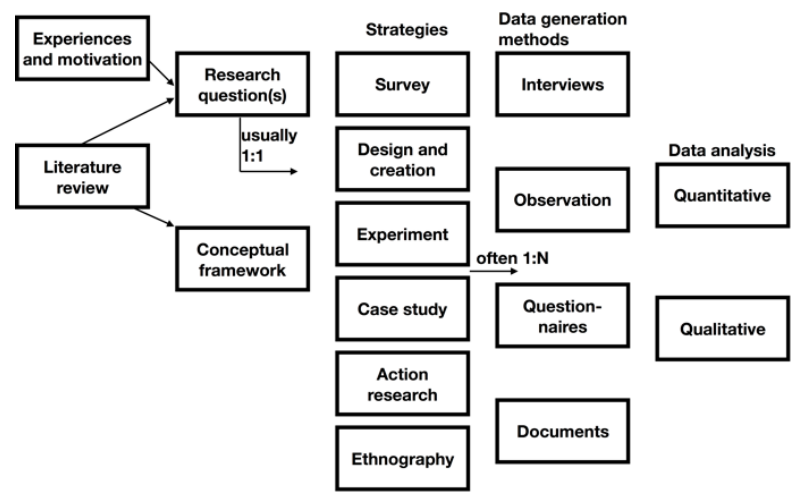

Figure 2: Model of the research process (Oates, 2005)

Oates (2005) also notes the process and components for doing research (Figure 2): "personal experiences and motivation, literature review, research question, conceptual framework, strategies, data generation methods and quantitative and/or qualitative data analysis" (Oates, 2005, p. 33).

As the many reasons to why people do research, so can the age distribution of PhD-students vary. Figure 3 presents the age distribution of PhD-students in a 2016 survey (The Swedish Higher Education Authority, 2016). Why is age important? It is because although the survey does not cover it, some doctoral students may have had a professional career, or are still practitioners in their professional field with many years of experience: these are also known as 'pracademics' (Dickinson, Fowler \& Griffiths, 2020).

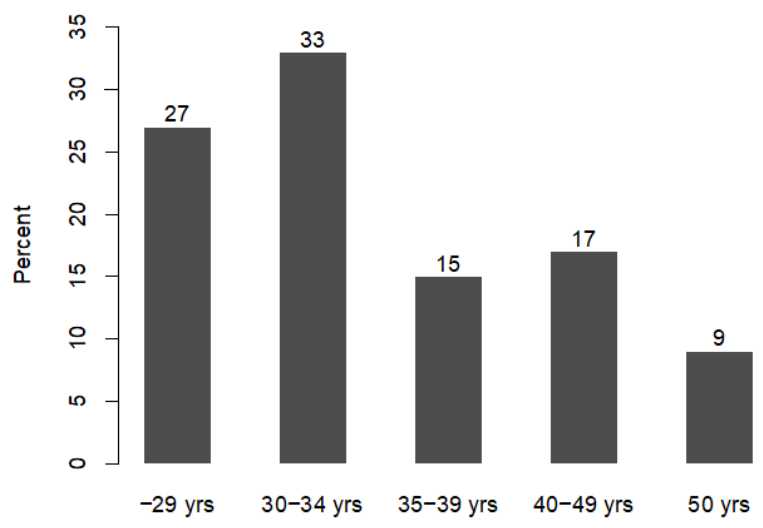

Figure 3: Age distribution (\%) of PhD-students. 
The author of this article falls within the 40-49 years age distribution. His reasons about why doing research on offensive cyberspace operations is based on his personal experiences during his professional career serving in the Swedish Armed Forces and the United Nations (UN), holding numerous intelligence and security positions including Director Intelligence in cyber-related issues and as Head of the UN's Intelligence Cell in a mission area for several years. In addition, he is a Veteran, with more than five years of duty in conflict and post-conflict areas including tours to the Balkans and in Central Asia. He was decorated with dual Non-Article 5 NATO Medals - and the Swedish Armed Forces International Service Medal of Reward for his tours to the Balkans and Central Asia.

These positions were held as a result of the professional training and education and achievements of each held role leading to measurable results. Having done a career with more than 20 years in the security and intelligence and interacting with numerous people ranging from those who had lost everything in a conflict to Ambassadors and Generals from various States and cultures, provide additional experiences which can never be gained by reading a book, or by taking a course. The book and the course may be a prerequisite to get a minimum threshold of understanding of the task at hand, but the experiences achieved after the engagement are based on that particular reality that existed at that particular time and space in that particular part of the world. Regardless of position held during these years, the problems have been complex. These complex problems included to provide a safe and secure environment (SASE) so people could build their lives, so economies could begin to grow, and governments could be built to govern, while in other areas to end conflict. As a security and intelligence professional, the purpose was to understand these complex problems, and based on this understanding, knowing the political landscape, identify the threats that were seeking to harm staff, assets and operations; identify the vulnerabilities that one self's organisation could have; and identify the associated risks. This was a continual collection of information, continual processing and analysis, and producing intelligence products in different formats. The observant reader notes that these steps are in a cyclical way, just like the intelligence cycle, and the problem, to collect information about the problem from different sources, to process, analyse and produce an intelligence product, reminds of the same steps as in Oates' (2005) model of the research process. Another model which is even more similar to the intelligence cycle in Figure 1 and widely used in research is Yin's (2018) case study research process (Figure 4).

\section{The Research Project}

The personal experiences and motivation for undertaking a doctoral project in offensive cyberspace operations is about understanding what offensive operations entail based on the author's 20+ years of experiences in a national and international setting as a security and intelligence professional, who's intelligence products are very similar to research products. The purpose with the project is to generate understanding to policy-makers, military leaders, academics and the general population, so Sweden can use offensive cyberspace operations for deterrence and defence: to defend Swedish national interests.

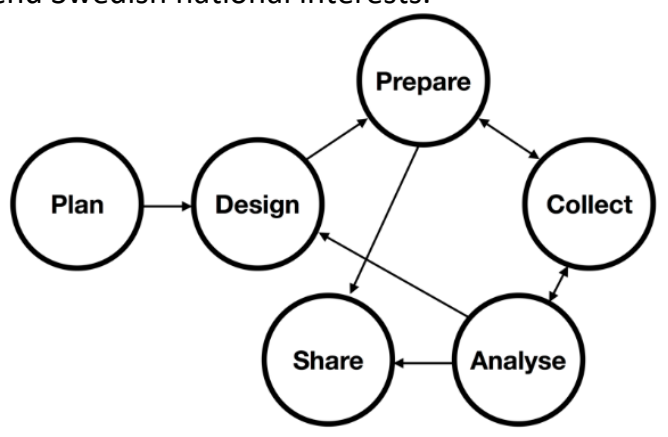

Figure 4: Case study research process (Yin, 2018)

The doctoral project consists of two components: an education part and a training part. The education part is about understanding the different research philosophies, and how these philosophies affect the approach to theory development, methodological choice, research strategies, potential time horizons, and techniques and procedures for data generation and data analysis. Saunders (2016) has dubbed this as the "research onion." The research project is based on three theories: deterrence theory, cyberspace operations theory and intelligence theory. From a philosophical point of view, a researcher can be standing on the research philosophy of positivism, interpretivism or pragmatism (Saunders, 2016). This affects the approach to theory development: deduction, abduction or induction, which in turn affects the methodological choice: mono quantitative or qualitative methods, multi-methods or mixed methods (Saunders, 2016). Finally, the choice of research 
strategies (e.g., survey, action research, experiment, case study) affect the choice of data collection/data generation and analysis methods or techniques (Saunders, 2016).

Based on the personal experiences, motivation and philosophical stance (interpretivism), with related strategies (case study), data generation (e.g., interviews, observations) and analysis methods (e.g., thematic analysis), the training part of the doctoral project is about the planning and execution of research activities that lead to research products. The research products are double-blind peer reviewed, and after taking into account the reviewer's comments, the results are published in an acceptable venue. The output of this research project, using "The General Method of Theory-Building Research in Applied Disciplines" (Lynham, 2002), has been ten research articles published in conference proceedings and in one journal (Bengtsson \& Huskaj, 2021; Granåsen, Huskaj \& Varga, 2019; Huskaj \& Moradian, 2018; Huskaj, 2019; Huskaj \& Wilson, 2020a; Huskaj \& Wilson, 2020b; Huskaj, Wilson \& Iftimie, 2020; Huskaj \& Wilson, 2021a; Iftimie \& Huskaj, 2020; Kävrestad \& Huskaj, 2021), one report (Huskaj \& Sallinen, 2021d), and three unpublished works (Huskaj, 2018; Huskaj, 2021b; Huskaj 2021c). This article is not included in that count. Finally, an academic course (Cyber Operations in Antagonistic Environments) on advanced level at the Swedish Defence University is heavily based on the results of this research. It is very likely that these research products have been significantly influenced by this author's background, experiences, and expertise to identify a problem, plan, prepare, collect, analyse, produce and disseminate intelligence products: Figures 1, 2 and 4 show the close, if not equal, resemblance between intelligence operations and related work with scientific research.

\section{The Method and Linguistic Analysis}

The method to quantify 'substantial' is depicted in Figure 4. The limitations of this method include: if the assumption is different (e.g., the main author does less than 50\%); qualitatively, if no principles, recommendations or guidelines exist in a particular field, it is not possible to apply linguistic analysis (Goldkuhl, 2002).

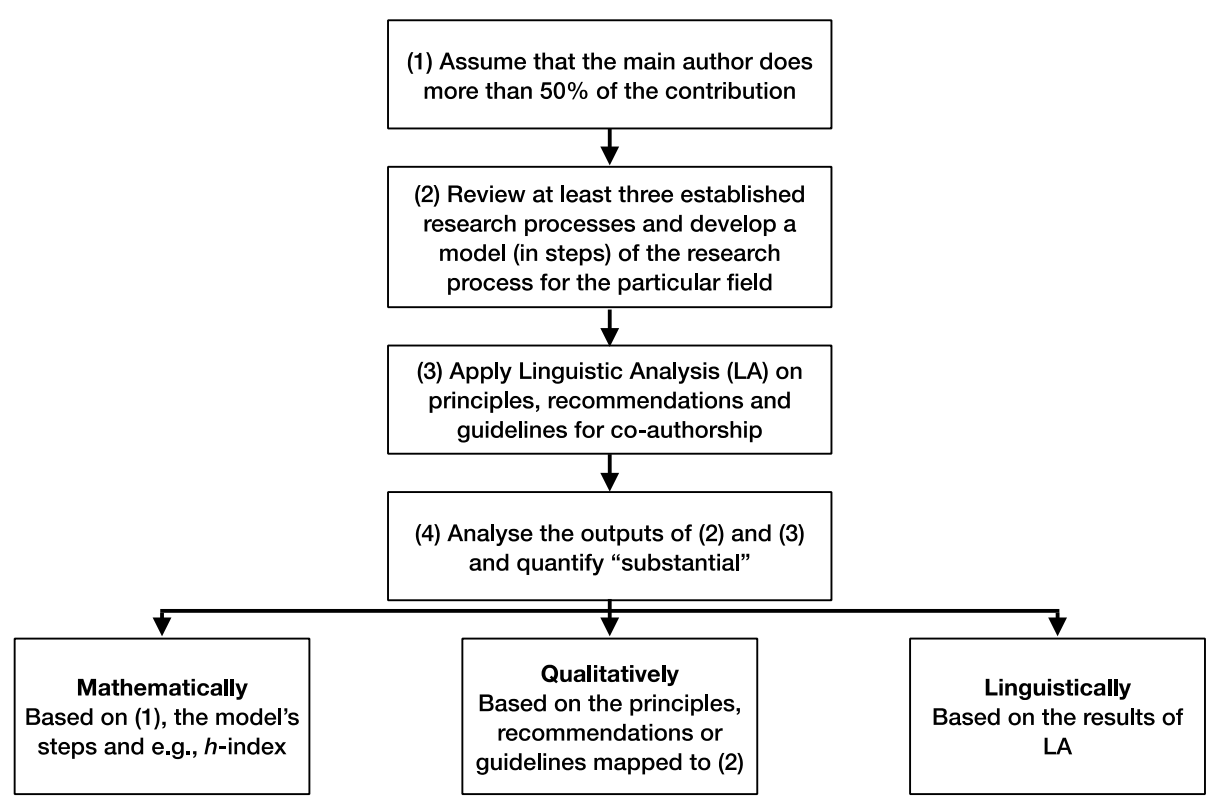

Figure 4: The method to quantify substantial

The doctoral project is done within a research discipline and supported by several supervisors. The supervisors supervise, a verb which means "to look over" and is "from Medieval Latin supervisus, past participle of supervidere 'oversee, inspect'” (Etymology Dictionary [herein ED], 2021b). In other words, the supervisors look over, oversee, and inspect the doctoral student's research activities that lead to research products published in an acceptable venue. However, to look over, oversee, and inspect, implies that certain formal requirements must be met. These formal requirements are, for the main supervisor, "at least docent competence is required" (HiS, 2017, p.2); for the primary and assistant supervisor, "at least a doctoral degree" (HiS, 2017, p. 2). These formal requirements are always met. Furthermore, while supervising (to look over, oversee, and inspect) the supervisor(s) have an important role to review (inspect) the doctoral student's work:

"Normally, research students and supervisors collaborate in the production of scientific work. It is therefore common for both research students and supervisors to be stated as co-authors of these works, 


\section{Gazmend Huskaj}

provided that the supervisor has participated in the production of the publication and / or the intellectual work on which the publication is based" (HiS, 2017, p. 5).

The above states that "research students and supervisors collaborate in the production of scientific work" and that this is "normally" done. Collaborate, a verb from 1845 means "to work with another or others" (ED, 2021c). Production, a noun, stems from produccioun meaning "a coming into being", a "noun of action" (ED, 2021d). The verb "produce" is from the early $15^{\text {th }}$-century producen, to "develop, proceed, extend, lengthen out" (ED, 2021e). Finally, "normally" an adverb from the 1590s, means "regularly, according to general custom" (ED, 2021f).

In other words, according to general custom (=normally), those who look over, oversee, and inspect (=supervisors), work with another [e.g., the research student] or others, and take actions to put something into being (=production), or develop (an action, =produce) (e.g., the research product).

The next sentence states that the research student and those who look over, oversee, and inspect are "stated as co-authors of these works" (=research products). The word "author", a noun, is from the mid $14^{\text {th }}$-century and stems from auctor, autour, autor, meaning "father, creator, one who brings about, one who makes or creates" (ED, 2021g). The Latin auctour means "promoter, producer, father, progenitor; builder, founder; trustworthy writer, authority; historian; performer, doer; responsible person, teacher" (ED, 2021g). The observant reader notes "producer", a noun, from the 1510s which means "one who or that which produces" (ED, 2021h), an agent noun from the verb "produce".

In other words, the research student and those who look, oversee and inspect are stated as "fathers, creators, [those] who bring about" the research product. The "one(s) who or that which produces" (=producer) take actions to develop (an action, =produce) a research product.

In conclusion, according to general custom (=normally), those who look over, oversee, and inspect (=supervisors), work with another [e.g., the research student] or others, and take actions to put something into being (=production), or develop (an action, =produce) (e.g., the research product), and the research student and those who look, oversee and inspect are stated as "fathers, creators, [those] who bring about" (=authors) the research product. The "one(s) who or that which produces" (=producer) take actions to develop (an action, =produce) a research product.

Now, consider "provided that the supervisor has participated in the production of the publication and / or the intellectual work on which the publication is based" (HiS, 2017, p. 5). The keyword here is "participated", the past tense verb of "participate." Participate, a verb, is from the 1530s and means "to partake, to share or share in" (ED, 2021i). The noun, participation, means "act or fact of sharing or partaking in common with another or others; act or state of receiving or having a part of something" (ED, 2021j).

In other words, those who look over, oversee and inspect (=supervisors) take actions (=verb) "to partake, to share or share in" (=participate) to develop a "written or printed work" (=publication) (ED, 2021k).

The observant reader notes that nothing is mentioned about how much actions are required by the research student and the supervisors to be considered as "creators" or "producers" (=authors) of the research product. In other words, "nothing is mentioned about the size of the contribution of the co-author in question" (NTNU, 2021). Because of this, co-authorship can lead to "frustration and conflicts" (NTNU, 2021). To combat frustration and conflicts, different principles, recommendations and guidelines have been produced. Offutt (2015) states that, as a general principle, "Everyone who makes substantial contributions to the results is a co-author on papers that present those results" (p. 73). NTNU (2021) states that, as a general principle, "decide who is a coauthor and how the co-authors will contribute already at the beginning of the publication process". Offutt (2015) seems to agree by stating that "it is very important that authorship must be discussed openly, objectively, and rationally. This conversation should happen before the paper is started" (p. 74). However, even Offutt (2015, p. 74) wonders: "What is a substantial contribution?" While Offutt (2015), based on his experience, provides a list (not comprehensive) of circumstances where authorship is warranted, the Vancouver Recommendations, drawn by the International Committee of Medical Journal Editors (ICMJE) (The Norwegian National Research Ethics Committees, 2020) provides the recommendation "that authorship be based on the following 4 criteria: 


\section{Gazmend Huskaj}

1. Substantial contributions to the conception or design of the work; or the acquisition, analysis, or interpretation of data for the work; AND

2. Drafting the work or revising it critically for important intellectual content; AND

3. Final approval of the version to be published; AND

4. Agreement to be accountable for all aspects of the work in ensuring that questions related to the accuracy or integrity of any part of the work are appropriately investigated and resolved." (ICMJE, p.2).

This recommendation is also provided by several Swedish universities (e.g., Karolinska Institutet, Mid Sweden University, Umeå University; University of Skövde): "All those designated as authors should meet all four criteria for authorship, and all who meet the four criteria should be identified as authors" (ICMJE, 2019, p. 2). The keyword, as Offutt (2015) and ICMJE (2019) state is "substantial." Substantial is an adjective and stems from the mid $14^{\text {th }}$-century, meaning "ample, sizeable" (ED, 2021l). Ample, an adjective, stems from the $12^{\text {th }}$-century "from Old French ample "large, wide, vast, great"” (ED, 2021m). In the $15^{\text {th }}$-century, it meant "great, abundant." Sizeable, an adjective from the 1620s means "of relative good, suitable, or desirable size, usually somewhat large" (ED, 2021n).

In other words, substantial, means large, wide, vast, great (=ample) or of relative good, suitable, or desirable size, usually somewhat large (=sizeable). The Swedish equivalent "betydande" means "som spelar en stor roll, som utövar stort inflytande, framstående, vidgående" (SAOB, 2021), and is comparable to "ansenlig, avsevärd" (Svensk ordbok, 2021). The adjective substantial is about the size of something relative to something else, and the size is desirable, an adjective from the verb desire, "from the Latin desidare "long for, wish for; demand, expect'" (ED, 20210). Thus, quantifying the size and deeming it desirable means that the entity that is longing for, wishing for, or demanding or expecting, has to express and describe it in qualitative and/or quantitative terms.

Applying the above in an academic research project with related activities where the output is a research product leads to the following reasoning. The output of a research project is a research product. The research product is commonly organised around abstract, introduction, literature review, methods, results and discussion. Conclusions may be omitted but are welcome if they bring further clarity to the topic. However, for a research product to come to life, substantial effort is required by the engaged researcher. Saunders (2016) "research onion" presents the steps in a research project: six in total. Goldkuhl (2020) presents the research activities as "formulating research questions, choose appropriate research strategies and methods for collecting / generating data, coding/analysing the data, concept formation (i.e., defining concepts), and the formulation of theoretical statements." Goldkuhl (2020) presents six steps. Oates (2005) presents seven steps. However, while the steps may differ, they are not in a one-to-one-relation. Oates (2005) mentions "personal experiences, motivation and literature review" while the other two do not mention these. Both Goldkuhl (2020) and Saunders (2016) discuss the philosophical aspects of research, while this is not apparent in Oates' (2005) research model. The remaining steps overlap.

The researchers have another step in common: the absence of the writing process. None of them mention the writing process in their models: the writing that is required to produce the research product that presents the results of the research project to a greater audience. However, Saunders (2016) has a whole chapter on "writing and presenting your project report" (pp. 628 -673). Finally, none of the authors mention the review process a research product undergoes before publication.

Therefore, a more precis model of a research project is:

Personal experiences and motivation, understand the different research philosophies, and how these research philosophies affect the approach to theory development, methodological choice, research strategies, potential time horizons, and techniques and procedures for data generation and data analysis. Next, identify a problem and/or research idea, review the literature, conceptualise, generate a research question, generate a research aim and/or objectives, choose a relevant research design (which is "the general plan of how you will go about answering your research question(s)" (Saunders, 2016, p. 163)). The research design can be quantitative, qualitative or mixed methods (Saunders, 2016). A qualitative research design "is often associated with an interpretive philosophy" (Saunders, 2016, p. 168), has an abductive or inductive approach, and is linked to a qualitative data collection/generation technique/method such as semi-structured interviews (Saunders, 2016). The analysis is done using relevant data analysis methods, and the research strategy can be case study. After the 
data analysis is done, it is then time to produce the first draft according to the steps as depicted in Table 1 (Borja, 2021). Note that although a qualitative research design was used to exemplify, all academic research can apply.

Table 1: The steps to produce the first draft of a research product

\begin{tabular}{|c|c|c|c|}
\hline Step & Action & Step & Action \\
\hline 1 & Prepare the figures and tables & 7 & Write the Abstract \\
\hline 2 & Write the Methods & 8 & $\begin{array}{l}\text { Compose a concise and } \\
\text { descriptive Title }\end{array}$ \\
\hline 3 & Write up the Results & 9 & $\begin{array}{l}\text { Select Keywords for } \\
\text { indexing }\end{array}$ \\
\hline 4 & $\begin{array}{l}\text { Write the Discussion. Finalize the Results and Discussion before writing the } \\
\text { introduction. This is because, if the discussion is insufficient, how can you } \\
\text { objectively demonstrate the scientific significance of your work in the } \\
\text { introduction? }\end{array}$ & 10 & $\begin{array}{l}\text { Write the } \\
\text { Acknowledgements }\end{array}$ \\
\hline 5 & Write a clear Conclusion & 11 & Write up the References \\
\hline 6 & Write a compelling introduction & & \\
\hline
\end{tabular}

Then, write a cover letter, upload the manuscript and send it to the Journal and respond to eventual comments sent by the editor and/or anonymous reviewers responsible for the double-blind peer review.

In summary, a model of a research project is as follows. Based on personal experiences and motivation, understand the different research philosophies, and how these research philosophies affect the approach to theory development, methodological choice, research strategies, potential time horizons, and techniques and procedures for data generation and data analysis. Table 2 presents a model of a research project in offensive cyberspace operations consisting of 27 steps.

Table 2: A model of a research project in offensive cyberspace operations

\begin{tabular}{|l|l|l|l|}
\hline Step & Action & 15 & Write a clear Conclusion \\
\hline 1 & Identify a problem and/or research idea & 16 & Write a compelling introduction \\
\hline 3 & Review the literature & 17 & Write the Abstract \\
\hline 4 & Conceptualise & 18 & $\begin{array}{l}\text { Compose a concise and descriptive } \\
\text { Title }\end{array}$ \\
\hline 5 & Generate a research Question & 19 & Select Keywords for indexing \\
\hline 6 & $\begin{array}{l}\text { Choose a relevant research design (e.g., qualitative). A } \\
\text { qualitative research design implies an interpretative philosophy } \\
\text { with an abductive or inductive approach }\end{array}$ & 20 & Write the Acknowledgements \\
\hline 7 & $\begin{array}{l}\text { Choose a research strategy (the plan to achieve the goal). A } \\
\text { qualitative research strategy can be Case Study }\end{array}$ & 21 & Write up the References \\
\hline 8 & $\begin{array}{l}\text { Choose one/several data collection/generation } \\
\text { technique(s)/methods (e.g., semi-structured interviews, self- } \\
\text { reporting) }\end{array}$ & 22 & Write a cover letter \\
\hline 9 & Collect the information & 23 & Upload the manuscript \\
\hline 10 & $\begin{array}{l}\text { Analyse the collected data using qualitative procedures } \\
\text { (n) }\end{array}$ & $\begin{array}{l}\text { Respond to the journal's decision, } \\
\text { which may include: }\end{array}$ \\
\hline 11 & Prepare the figures and tables & 25 & Respond to the editor \\
\hline 12 & $\begin{array}{l}\text { Write the Methods } \\
\text { insufficient, how can you objectively demonstrate the scientific } \\
\text { significance of your work in the introduction? }\end{array}$ & $\begin{array}{l}\text { Review the comments from the } \\
\text { double-blind peer reviewers, and } \\
\text { edit the manuscript where needed }\end{array}$ \\
\hline 13 & Write up the Results & Re-send the manuscript \\
\hline 14 & $\begin{array}{l}\text { Write the Discussion. Finalise the Results and Discussion before } \\
\text { writing the introduction. This is because, if the discussion is }\end{array}$ & & \\
\hline
\end{tabular}

What does this have to do with a substantial contribution? Recall that the adjective substantial is about the size of something relative to something else, and the size is desirable, an adjective from the verb desire, which is "from the Latin desidare 'long for, wish for; demand, expect" (ED, 20210). Thus, quantifying the size and deeming it desirable means that the entity that is longing for, wishing for, or demanding or expecting, has to express and describe it in qualitative and/or quantitative terms. Thus, the total size of a research project in offensive 
cyberspace operations consists of 27 steps. While some steps in the model require less effort, others do not. Data collection may go quickly, but the analysis may take time (e.g., manual instead of computational). Furthermore, while writing the first draft of a research product aimed for a journal may take 12 weeks (Belcher, 2009), the response to the journal's decision may take an equal amount of time depending on the outcome: e.g., desk reject or major revisions.

\section{Quantifying Substantial}

To quantify substantial mathematically without taking into account any temporal aspects could be to contribute by conducting 13 of the 27 steps. It is assumed that a substantial contribution does not equal to $50 \%$ of the work. To quantify substantial qualitatively could be that the first author conducts step 1-23, and the co-author 24-27. This approach assumes the co-author has significant experience in the academic field. To make this tangible, the $h$-index, which compares "the productivity and impact of published work of scholars" (Scopus, 2021), can be applied. Based on the author's experience, a co-author with an $h$-index of $38, h$-index of 16 , or $h$-index of 11 is expected to provide in less steps than a co-author with a lower $h$-index. A co-author with a lower $h$-index is expected to contribute more, but never $50 \%$ of the work.

Another way of quantifying substantial is by taking into account the Vancouver Recommendations as mentioned earlier. There are four criteria, and these four are bound by an AND boolean-operator. Therefore, the first criteria are about conception of the work (steps 1 - 5); or design of the work (steps 6 -8); or the acquisition (step 9); analysis (step 10); or interpretation of data for the work (step 11); AND

Drafting the work (steps 12 - 16) or revising it critically for important intellectual content (steps 12 - 17); AND Final approval of the version to be published (review steps 12 - 21); AND

Agreement of accountability.

The observant reader may note that the Vancouver Recommendations only take into account the first draft of the paper and does not cover steps 22 - 27. Finally, a mixed approach of the above scenarios can also be taken.

Therefore, the answer to the question "What is a substantial contribution to a research project in cyberspace operations that merits co-authorship" is: scientific actions taken by a co-author to ensure that a contribution to a research project is of desirable size relative to the total size of the research project which lives up to the wishes, demands or expectations of the first author where the output of the scientific actions is a research product. The related steps: cover letter, upload of the manuscript and responses to the journal's decision should preferably be discussed before the research project begins.

\section{Conclusions and Why is this Important?}

A PhD-project spans over several years and the psychological and emotional aspects coupled with e.g., busy supervisors, different views on co-authorship, and being inexperienced compared to the PhD-student, are all elements that can lead to frustration and conflict. The answer to the research question (as noted above) means a co-author in a research project in offensive cyberspace operations has to do some actual work where the output is a research product. Because PhD-students have different backgrounds (traditional, professional, pracademic), it is important for all of the involved parties in a PhD-project to understand that the needs, education and training may differ among the three mentioned categories of PhD-students. Senior academics should not be surprised if a professional PhD-student disagrees on co-authorship because the wishes, demands or expectations of the first author are not met. This is especially true if the supervisors take time to provide feedback, are not invested in the PhD-project (=being away for four years and wanting to invest $5 \%$ of one's time is not enough), not providing enough of support, being too busy (=2 years post-doc studies and an additional 1.5 years on a MSc-education), having different perspectives on co-authorship ("I had to write everything when I was a PhD-student and my professor just put his/her name on as co-author"), and being inexperienced in comparison to the PhD-student, are all elements that have led to no research products co-authored with the supervisors. To just review a draft manuscript and saying "this is good, now you can put my name on it" is not a substantial contribution and will not suffice for co-authorship.

\section{Acknowledgements}

I'd like to thank my former junior supervisors (in alphabetical order) Marcus Nohlberg and Johan Sigholm for inspiring me to write this article. 


\section{Gazmend Huskaj}

\section{References}

Bengtsson, J. \& Huskaj, G. (2021). The Manifestation of Chinese Strategies Into Offensive Cyberspace Operations Targeting Sweden. In: 20th European Conference on Cyber Warfare and Security / [ed] Dr. Thaddeus Eze, Dr. Lee Speakman and Dr. Cyril Onwubiko, Chester, 2021, p. 35-43.

Belcher, W.L. (2009)., Writing your journal article in 12 weeks: A Guide to Academic Publishing Success. SAGE Publications. Borja, A. (2021). 11 steps to structuring a science paper editors will take seriously. Retrieved from https://www.elsevier.com/connect/11-steps-to-structuring-a-science-paper-editors-will-take-seriously.

Dickinson, J. Fowler, A. \& Griffiths, T.L. (2020). Pracademic expertise and its value to higher education. Retrieved from https://www.advance-he.ac.uk/news-and-views/pracademic-expertise-and-its-value-higher-education.

Etymology Dictionary. (2021a). Motivation (n.). Retrieved from https://www.etymonline.com/search?q=motivation.

ED (2021b). Supervise (v.). Retrieved from https://www.etymonline.com/search?q=supervise.

ED. (2021c). Collaborate (v.). Retrieved from https://www.etymonline.com/search?q=collaborate.

ED. (2021d). Production (n.) Retrieved from https://www.etymonline.com/search?q=production.

ED. (2021e). Produce (v.). Retrieved from https://www.etymonline.com/word/produce?ref=etymonline_crossreference\#tetymonline_v_2617.

ED. (2021f). Normally (adv.). Retrieved from https://www.etymonline.com/word/normally\#etymonline_v_35603.

ED. (2021g). Author (n.). Retrieved from https://www.etymonline.com/word/author\#etymonline_v_18965.

ED. (2021h). Producer (n.). Retrieved from https://www.etymonline.com/word/producer\#etymonline_v_30401

ED. (2021i). Participate (v.). Retrieved from https://www.etymonline.com/search?q=participate.

ED. (2021j). Participation (n.) Retrieved from https://www.etymonline.com/word/participation?ref=etymonline_crossreference.

ED. (2021k). Publication (n.) Retrieved from https://www.etymonline.com/search?q=publication.

ED. (2021l). Substantial (adj.). Retrieved from https://www.etymonline.com/word/substantial\#etymonline_v_22270.

ED. (2021m). Ample (adj.) Retrieved from https://www.etymonline.com/word/ample\#etymonline_v_11020.

ED. (2021n). Sizeable (adj.). Retrieved from https://www.etymonline.com/word/sizeable\#etymonline_v_38192.

ED. (20210). Desire (v.). Retrieved from https://www.etymonline.com/word/desire?ref=etymonline_crossreference\#etymonline_v_5657.

Goldkuhl, G. (2002). Anchoring scientific abstractions - ontological and linguistic determination following socioinstrumental pragmatism. European Conference on Research Methods in Business and Management (ECRM 2002), Reading, 29-30 April 2002.

Goldkuhl, G. (2020). Kvalitativ forskning: frågor, data, teori. Presentation.

Granåsen, M., Huskaj, G., \& Varga, S. (2019). Data Collection and Research in CDXs - Command and Control, Cyber Situational Awareness and Intelligence Perspectives on Cyber Defense. In 24th International Command and Control Research \& Technology Symposium (p. 20). Laurel.

HiS. (2017). Riktlinjer. Retrieved from https://www.his.se/globalassets/dokument/styrdokument/riktlinjer-handledningstudieuppfoljning-utbildning-forskarniva.pdf.

HiS. (2019). Riktlinjer för vetenskapligt författarskap. Retrieved from https://www.his.se/globalassets/tillfalligadokument/styrdokument/forskning-och-utbildning-pa-forskarniva/riktlinjer-for-vetenskapligt-forfattarskap.pdf.

Huskaj, G. (2018). A computational literature review of cyberspace operations. Unpublished work.

Huskaj, G., \& Moradian, E. (2018). Cyber Deterrence: An Illustration of Implementation. In J. Hurley \& J. Chen (Eds.), 13th International Conference on Cyber Warfare and Security (pp. 304-311). Washington D.C.: Academic Conferences and Publishing International Ltd.

Huskaj, G. (2019). The Current State of Research in Offensive Cyberspace Operations. In T. Cruz \& P. Simoes (Eds.), 18th European Conference on Cyber Warfare and Security (pp. 660-667). Academic Conferences and Publishing International Ltd.

Huskaj, G., \& Wilson, R. L. (2020a). An Anticipatory Ethical Analysis of Offensive Cyberspace Operations. In P. B. K. Payne \& P. H. Wu (Eds.), ICCWS 2020 15th International Conference on Cyber Warfare and Security (pp. 512-520). Norfolk: Academic Conferences and Publishing International Limited.

Huskaj, G. \& Wilson, R.L. (2020b). Anticipatory Ethics for Vulnerability Disclosure. In: Proceedings of the 15th International Conference on Cyber Warfare and Security / [ed] Payne, Brian K.; Wu, Hongyi, Reading, UK: Academic Conferences and Publishing International Limited, 2020, pp. 254-261.

Huskaj, G., Iftimie, I. A., \& Wilson, R. L. (2020). Designing attack infrastructure for offensive cyberspace operations. In European Conference on Information Warfare and Security, ECCWS (Vol. 2020-June, pp. 473-482).

Huskaj, G., \& Wilson, R. L. (2021a). Offensive Cyberspace Operations and Zero-days: Anticipatory Ethics and Policy Implications for Vulnerability Disclosure. Journal of Information Warfare, 20(1), 96-109.

Huskaj, G. (2021b). How do Smart States Organize Cyberspace Capabilities? The Swedish Case. Unpublished work.

Huskaj, G. (2021c). Testing a Framework for Offensive Cyberspace Operations. Unpublished work.

Huskaj, G. \& Sallinen, M. (2021d). Staters outtalade normer i cyberrymden. Retrieved from http://fhs.divaportal.org/smash/get/diva2:1576646/FULLTEXT02.pdf.

ICMJE. (2019). Recommendations for the Conduct, Reporting, Editing, and Publication of Scholarly Work in Medical Journals. Retrieved from http://www.icmje.org/icmje-recommendations.pdf. 
Iftimie, I.A. \& Huskaj, G. (2020). Strengthening the cybersecurity of smart grids: The role of artificial intelligence in resiliency of substation intelligent electronic devices. In: Proceedings of the 19th European Conference on Cyber Warfare and Security: a virtual conference hosted by University of Chester UK 25-26 June 202 / [ed] Thaddeus Eze, Lee Speakman, Cyril Onwubiko, Reading: Academic Conferences and Publishing International Limited, 2020, pp. 143-150.

Joints Chiefs of Staff. (2013). Joint Publication 2-0: Joint Intelligence. Retrieved from https://www.jcs.mil/Portals/36/Documents/Doctrine/pubs/jp2_0.pdf.

Kävrestad, J. \& Huskaj, G. (2021). How the Civilian Sector in Sweden Perceive Threats from Offensive Cyberspace Operations. In: 20th European Conference on Cyber Warfare and Security / [ed] Dr. Thaddeus Eze, Dr. Lee Speakman and Dr. Cyril Onwubiko, Chester: Academic Conferences and Publishing International Limited, 2021, pp. 499-506.

Morrison-Saunders, A., Moore, S.A., Hughes, M. and Newsome, D. (2010). Coming to terms with research practice - Riding the emotional rollercoaster of doctoral research studies. In: Thomson, P. and Walker, M., (eds.) The Routledge doctoral student's companion: getting to grips with research in education and the social sciences. Routledge, New York.

Lynham, S.A. (2002). The General Method of Theory-Building Research in Applied Disciplines. Advances in Developing Human Resources 2002; 4; 221 DOI: 10.1177/1523422302043002.

NTNU. (2021). Co-authorship. Retrieved from https://innsida.ntnu.no/wiki/-/wiki/English/Co-authorship.

Nelson, M.L. \& Friedlander, M.L. (2001). A Close Look at Conflictual Supervisory Relationships: The Trainee's Perspective. Journal of Counseling Psychology. 2001, Vol. 48, No. 4, pp. 384-395.

Nygaard, L.P. (2017). Publishing and perishing: an academic literacies framework for investigating research productivity. Studies in Higher Education, 42:3, pp. 519-532, DOI: 10.1080/03075079.2015.1058351.

Oates, B. J. (2005). Researching Information Systems and Computing (First). Sage Publications, Inc.

Offutt, J. (2015). Editorial: Who Is An Author?. Softw. Test. Verif. Reliab. 2015; 25:73-76. DOI: 10.1002/stvr.1571.

SAOB. (2021). Betydande. Retrieved from https://svenska.se/saob/?id=B_2123-0004.wdK4\&pz=3.

Saunders, M. N. K., Lewis, P., \& Thornhill, A. (2016). Research Methods for Business Students (7th ed.). Harlow: Financial Times/Prentice Hall.

Scopus. (2021). Scopus. Retrieved from https://www.scopus.com.

Svensk ordbok. (2021). Betydande. Retrieved from https://svenska.se/so/?sok=betydande\&pz=4.

The Norwegian National Research Ethics Committees. (2020). The Vancouver Recommendations. Retrieved from https://www.forskningsetikk.no/en/resources/the-research-ethics-library/legal-statutes-and-guidelines/thevancouver-recommendations/.

The Swedish Higher Education Authority. (2016). Doktorandspegeln - en enkät om doktorandernas studiesituation. Retrieved from https://www.uka.se/publikationer--beslut/publikationer--beslut/rapporter/rapporter/2016-12-08brister-i-doktoranders-handledning.html.

Times Higher Education. (2017). Of monsters and mentors: PhD disasters, and how to avoid them. Retrieved from https://www.timeshighereducation.com/features/monsters-and-mentors-phd-disasters-and-how-to-avoid-them.

Tschannen-Moran, M. \& Nestor-Baker, N. (2004). "The Tacit Knowledge of Productive Scholars in Education." Teachers College Record 106 (7): 1484-511. 